\title{
The Analysis of Phonology
}

\section{in First Language Acquisition Melayu Pattani in Children Three-Year-Old}

\author{
Idda Astia \\ Idda.astia@gmail.com \\ Humanities Faculty, Airlangga University, Surabaya, Indonesia
}

Received: 07 October 2020 Accepted: 01 December 2020

DOI: $10.24256 /$ ideas.v8i2.1601

\begin{abstract}
The study aims at finding out how the children in Pattani, Thailand acquire their first language acquisition. The study is focused on the children three-year-old due to the fact that they are able invited to communicate in two ways and already comprehend the time when their turn to talk and when other person's turn to talk. Therefore, the researcher wants to research the utterances in process of first language acquisition in phonology. The study is conducted to address the language acquisition in Melayu Pattani due to the fact that it does not identical in Melayu Malaysia. In addition, the study uses descriptive qualitative method for analyzing and describing the production of children utterance. The data were taken by recording and interviewing the children. Finally, it is inferred that children absolutely do the simplification, such as substitution, omission and assimilation to help them to produce the utterance when they make the conversation.
\end{abstract}

Keywords: first language acquisition; melayu Pattani; phonology; three-year-old children

\section{Introduction}

All people around the world use the language as a tool to communicate each other. Not only human does the communication but also other creature. Yet, the way to make communication between human and other creature are not the same. Language for human is more creative and flexible than the communicative system of other creature (Cairns and Cairns, 1976 in Tarigan, 2009; Purba, 2016). It is the privilege for the human due to the fact that they have the organs to produce the 
Idda Astia

The Analysis of Phonology in First Language Acquisition Melayu Pattani in Children Three-Year-Old

utterance which are not had by other creature. Biologically, the structure of humankind mouth is totally different with the structure of other creature mouth. Consequently, the human is able to produce the utterance and create the language. Human acquires the language which is started when they become a baby one-month-old to the age of five years through first language acquisition (Meniado, 2016; Noermanzah, 2017).

Language acquisition must be developed by human to improve the language skill. Acquisition and learning are two ways to improve the human language skill (Ratnaningsih, 2017). Nevertheless, language acquisition and language learning are not the same. Learning language connects to process happened when children learn the second language acquisition after acquiring the first language acquisition, (Chaer, 2009; Fatmawati, 2015). The process of learning language is done in formal education but the process of language acquisition is done naturally (Rosdiana, 2016). Furthermore, the interaction is given by surrounding environment will make the baby acquires the first language acquisition. Before the children are able to produce the utterance, children are industrious in collecting the information about their environment (Ardiana \& Sodiq, 2008; Dani, 2014; Hutauruk, 2015). In the process of language acquisition, children will be easier produce the utterance of noun. In Clark's point of view (2009) that noun is easier identified, but verb is more complex than noun for object and it is more difficult to be acquired. So that children will produce noun vocabulary than verb. Furthermore, children are able to acquire the language without explicitly taught with limited cognitive ability (Narafshan et al., 2014). They comprehend what the speaker say to them in the other hand they are only able to produce limited utterances due to the fact that they must get through some stages to get the perfect utterances. When the children are able to produce ten words, their comprehension are 1100 words; so that it becomes eleven times than their production, (Dardjowidjojo, 2003). Additionally, Clark (2009) also explains that children comprehend many words long before they can produce them, and this asymmetry between comprehension and production is lifelong.

When baby acquires first language, there are some stages which must be followed. It is same as baby learn to walk. They will follow the stages from crawling, standing by holding the furniture or wall and walking without holding. Acquiring the first language acquisition is more complex. There are some different phases which passed by children in their different age (Haswadi et al., 2018). This study subscribes the definition proposed by (Clark, 2009) as children go through a series of stages when they learn to talk which beginning with infancy, when they are unable to converse and do not yet understand any language. At six weeks old, they start producing the unclear sounds similar with consonant or vocal which is called cooing. They go from babbling at seven to ten months old which is the sounds started by consonant and followed by vocal. To support Clark's definition 
about the process of babbling, Dardjowidjojo (2003) said that the process of babbling produces the consonant bilabial stop and bilabial nasal then the vocal is /a/ which create the structure CV and produce repeatedly. Then, within a few months, they combine words and gestures, and produce their first word combinations around age two. This is followed by the production of ever more complex, adult like utterances, as they become active participants in conversation, taking turns and making appropriate contributions. Children also make the simplification of the utterances, such as substitution, assimilation and omission in the communication.

Substitution is to replace one segment to another segment. Children will replace the consonant sound that they are not able to produce to consonant sound that they are able to produce. Substitution is divided to five parts, they are gliding, fronting, stopping, voicing and devoicing, (Lust, 2006). First, gliding is the replacement of liquid [l] or [r] to [w] or [y], such as 'leg' to yek and 'ready' to wedi. Second, fronting is substitution of front consonants such as [t] or [d] for back such as velars [k] [g], such as 'kitty' to ditty. Third, stopping is the replacement of stop consonants to fricative and affricative, such as 'shoes' to tuid. Forth is voicing word initial consonants, such as 'pie' to bie or 'pocket' to bat. The last is devoicing final consonants, such as 'knob' to nop. Then, assimilation is the absorption of one segment to another segment. It refers to the effect of sounds on those preceding or following them within a word or across word-boundaries (Clark, 2009). Children apply assimilation to adjust the sound which the sound is familiar according to them (Ingram, 1989). Assimilation is divided to three parts, they are regressive assimilation, progressive assimilation and reduplication (Lust, 2006). First, regressive assimilation, such as 'duck' to g $\mathrm{k}$, 'doggy' to goggy, 'nipple' to mibu. Then, omission is to omit sound or syllable. It is divided to three parts, they are consonant cluster reductions, final consonant deletion, unstressed syllable deletion (Lust, 2006). First, consonant cluster deletion such as 'broke' to bok. Second, final consonant deletion such as 'it' to I-h. Third, unstressed syllable deletion such as 'banana' to 'naenə.

Furthermore, there are a lot of observations about first language acquisition(Dani, 2014; Fatmawati, 2015; Haswadi et al., 2018; Hutauruk, 2015; Narafshan et al., 2014; Ratnaningsih, 2017; Rosdiana, 2016). Theseprevious studies mentioned that language acquisition acquired since the children were in one month in which they started to give the signs to communicate and it was continued by some stages. In the other hand, these studies showed the general result in acquiring the first language acquisition in children. While, some other studies observed about the language acquisition in certain age, such as threeyear-old, have been already conducted(Charlina, 2018; Meniado, 2016; Purba, 2016; Safitri \& Nur Hakim, 2018; Sebayang, 2015; Suwandi, 2012). These studies analyzed deeply the way of children in acquiring the first language because mostly the children have different ability to give the utterance in the certain age. These 
previous studies decided to certain age for the children in order to figure out the pattern of first language acquisition specifically due to the fact that different age gives the effect to the children in producing the utterances.

Furthermore, the study concerns to children age three years old because they have got huge of vocabularies. It is caused that children three-year-old are able to communicate in turn even the pronunciation is not completely perfect. A child in age 3 is able to engage in longer dialogs beyond a few turns (Owens, 2000). Then, in the process of interaction, children there-year-old also conduct the simplification, in which, the simplification process is not observed in the previous studies. While, the phenomena of first language acquisition in children three-year-old is concerned to language which used only in one region of the country, it is Melayu Pattani language. Moreover, Melayu language generally is official language in Malaysia, Brunei Darussalam, Indonesia and Singapore but it is not in Thailand (Jehwae, 2014). In Thailand, majority uses Thai language as official language, in the other hand, it is different with South Thailand especially in three provinces (Pattani, Yala, Narrathiwat) which the majority uses Melayu Pattani language. Furthermore, this study is conducted to analyze how the children age three years old produce the phonology and simplification in acquiring the first language acquisition in Melayu Pattani language.

\section{Method}

Observing and analyzing the language acquisition needed the qualitative approach due to the fact that qualitative approach was significant in written words. Qualitative research was research that concern in analyzing and interpreting texts and interviews find out the meaningful patterns descriptive of a particular phenomenon (Auerbach \& Silverstein, 2003). Furthermore, the forms of words were preferred as the data in the research. The data in qualitative research were collected in the words or picture form rather than numbers, (Bogdan \& Biklen, 2007). Saldana (2011) also supported the statement of Bogdan and Biklen that the information or data collected and analyzed was consisting of textual materials such as interview transcripts, fieldnotes, and documents or visual materials. The data often contained quotation and try to describe what particular situation or view of the world like in narrative form. Therefore, descriptive qualitative method was conducted in this study.

The source of data in this study was children three-year-old. The reason was in that age, the children already comprehend the time when their turn to talk and when other person's turn to talk. According to (Owens, 2000) that a child in age 3 was able to engage in longer dialogs beyond a few turns. There were two children which used to be analyzed their utterances. The first child named Ni Anya Muromea whose parents come from South of Thailand, Pattani. The second child named Firdaus Thosungnen whose mother comes from South of Thailand, Pattani 
and father comes from Bangkok. Both of them grew and lived in Pattani and they acquired language acquisition in Melayu Pattani language.

Several procedures had to be taken to collect the data. There were 2 stages that the data were taken in conversation in spoken then it was transcribed and analyzed the first language acquisition in the transcription. The data collection was conducted by video recording between the parents and their children in dialogue. The parents asked their children with some questions about daily activities. The researcher did not get involve in the conversation due to the role of the researcher was to observe and analyze.

These were five steps to analyze the data. First, conversation consisted of sender (parents) and receiver (children) were collected. The second stage, the utterances were classified between target utterances and children utterances. The third stage, the utterances was translated. The utterances in Melayu Pattani translated to English. The fourth stage, the data were classified based on the simplification in children production, they were substitution, assimilation and omission. Finally, the last step was the analyzing of the data.

\section{Results and Discussion}

There were 26 data which was found by the researcher in one week based on the video recording. Those data were collected from the conversation between the children three-year-old and their family. Children's family were as the senders and children three-year-old were as receivers.

Substitution is the replacement of one segment to another segment. Children do the simplification in producing the utterances when they talk to the other people. They produce the substitution by changing one consonant to another consonant. The table below is the data of phonology acquisition on substitution. There are 5 data substitution which produced by children from 26 data. Child A produced 2 utterances on substitution and child B produced 3 utterances on substitution.

Table 1. Data of Phonology Acquisition on Substitution

\begin{tabular}{|c|c|c|c|c|c|}
\hline No. & $\begin{array}{c}\text { Target } \\
\text { utterance }\end{array}$ & Pronunciation & $\begin{array}{l}\text { Children's } \\
\text { utterance }\end{array}$ & Pronunciation & Translation \\
\hline 1. & Nasik & [n $\Lambda$ SII?] & Nacik & {$[\mathrm{n} \wedge \mathrm{tg}$ I] } & Rice \\
\hline 2. & Eko & [ekJ:] & Ejo & [edzว:] & Tail \\
\hline 3. & Kolah & [ko:la:h] & Koyah & [kJ:ja:h] & School \\
\hline 4. & Allah & [э:llo:h] & Oyoh & [э:jo:h] & God \\
\hline 5. & Jatoh & [dzAtbh] & Yaktoh & [j $\Lambda$ ?toh] & Fall \\
\hline
\end{tabular}

The first data is nasikas a target utterance in the other hand child A produces different by doing substitution. She produces nacik when she wants to eat rice. Nasih to nacihmeans phoneme /s/ change to $/ \mathrm{t} /$. It means she is not able 
The Analysis of Phonology in First Language Acquisition Melayu Pattani in Children Three-Year-Old

to produce the sound of alveolar fricative in the other hand she is able to produce the sound of alveopalatal affricative. The second data is eko as a target utterance in the other hand child A produces different by doing substitution. She produces ejo to mention the tail of animal. The word ekoto ejomeans phoneme $/ \mathrm{k} /$ change to $/ \mathrm{d} /$. It means she is not able to produce the sound of velar in the other hand she is able to produce sound of alveopalatal affricative.

Third until fifth data are produced by child B. In the third data, the target utterance is kolah, in the other hand she produces koyah. She substitutes the word kolahto koyah. She changes the phoneme /l/ to /j/ by applying gliding on substitution. It means that she is not able to produce sound of alveolar in the other hand she is able to produce the sound of palatal. The fourth data is Allah as target utterance in the other hand child B produces oyoh when she mentions God. The change Allah to Oyohmeans that she substitutes the phoneme /l/ to /j/ by applying gliding. It means that she is not able to produce the sound of alveolar in the other hand she is able to produce the sound of palatal. Furthermore, the last data is jatoh as target utterance. In the other hand, child B produces yaktoh due to the fact that she is not able to produce it correctly. She applies substitution by changing the consonant. Jatoh to yaktoh means she substitutes phoneme /d $/$ to $/ \mathrm{j} /$. it means that she is not able to produce the sound of alveopalatal affricative in the other hand she is able to produce palatal.

Substitution is not the only one in simplification which applied by children. They apply assimilation to produce the utterance. Assimilation is the absorption one segment to another segment. There are 3 data obtained from 26 data about assimilation. Child A produced 1 assimilation and child B produced 2 assimilation.

Table 2. Data of Phonology Acquisition on Assimilation

\begin{tabular}{|c|c|c|c|c|c|}
\hline No. & $\begin{array}{c}\text { Target } \\
\text { utterance }\end{array}$ & Pronunciation & $\begin{array}{l}\text { Children's } \\
\text { utterance }\end{array}$ & Pronunciation & Translation \\
\hline 1. & Bakok & [b^kכ:?] & Bakkok & [bı?kว:?] & Bangkok \\
\hline 2. & Duo & [dvo:] & Duwo & [duwo:] & Two \\
\hline 3. & Bomo & [bo:mว:] & Momo & [mo:mo:] & Nurse \\
\hline
\end{tabular}

The first data is bakok which produced by child A. In the other hand, she supposed to produce bakok as a target utterance. She applies assimilation to the utterance which is produced. She applies reduplication by adding the phoneme glottal [?] in the middle of the word. She adds glottal in the middle due to the utterance bakok has glottal in the end of the word. She simply articulates that utterance by repeating glottal in the middle and in the end. The second data are produced by child $\mathrm{B}$. In the word $d u o$, she makes the assimilation. When adult produces the utterance duo, it must be pronounced [dvo:] which there is only 1 consonant and 1 diphthong. In the other hand, she is not able to pronounce duo 
correctly then she articulates duo to be duwoby pronouncing sound [w] clearly. The third data is bomo as target utterance in the other hand child B applies reduplication by articulating momo. Both $/ \mathrm{b} /$ and $/ \mathrm{m} /$ are bilabial in the other hand, child B is not able to articulate /b/ as plosive and change by articulating /m/ as nasal.

After applying substitution and assimilation on the utterances, children also apply the omission on their utterances. Omission is the deletion on sound or syllable when children articulate the utterance. The omission on the syllable mostly omits the unstressed syllable. In the data below there are 18 data from 26 data. Mostly, children produce the utterances which have two syllables.

Table 3. Data of Phonology Acquisition on Omission

\begin{tabular}{|c|c|c|c|c|c|}
\hline No. & $\begin{array}{c}\text { Target } \\
\text { utterance }\end{array}$ & Pronunciation & $\begin{array}{l}\text { Children's } \\
\text { utterance }\end{array}$ & Pronunciation & Translation \\
\hline 1. & Kucing & [kutgin] & Cing & [tgin] & Cat \\
\hline 2. & Abah & {$[\Lambda \mathrm{b} \Lambda \mathrm{h}]$} & $B a h$ & {$[\mathrm{~b} \wedge \mathrm{h}]$} & Father \\
\hline 3. & Rumoh & [rumo:h] & Moh & [mo:h] & House \\
\hline 4. & Tepung & [tәррп] & Pung & [ppy] & Snack \\
\hline 5. & Nampang & {$[\mathrm{n} \wedge \mathrm{mp} \wedge \eta]$} & Pang & {$[\mathrm{p} \wedge \eta]$} & Iced juice \\
\hline 6. & Sakek & [s $\mathrm{k}$ kæ? $]$ & Kek & [kæ?] & Pain \\
\hline 7. & Geboh & [gəboh] & Boh & [boh] & Fall \\
\hline 8. & Senyak & [sәрц?] & Nyak & 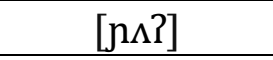 & Quiet \\
\hline 9. & Takok & [t $\Lambda \mathrm{kp} ?]$ & Kok & [kp?] & Afraid \\
\hline 10. & Jatoh & [yıtbh] & Toh & [tph] & Fall \\
\hline 11. & Tango & [ta:yj:] & $\mathrm{Ngo}$ & [уว: $]$ & Stairs \\
\hline 12. & Mokteh & [mว:Pteh] & Teh & [teh] & Mother \\
\hline 13. & Kampong & [kımppn] & Pong & [ppy] & Village \\
\hline 14. & Bangak & {$[\mathrm{b} \Lambda \mathrm{\eta} \Lambda \mathrm{k}]$} & Ngak & {$[\mathrm{y} \Lambda \mathrm{k}]$} & Quick \\
\hline 15. & Haco & {$[\mathrm{h} \Lambda \mathrm{cb}]$} & Co & [cD] & Melting \\
\hline 16. & Hate & [hıte] & Te & [te] & Hit \\
\hline 17. & Cocok & [сэ:сэ:?] & Cok & [cכ:?] & Injection \\
\hline 18. & Rasulullah & [ro:sulullo:h] & Osululoh & [э:sulvlว:h] & $\begin{array}{c}\text { Prophet } \\
\text { Muhammad }\end{array}$ \\
\hline
\end{tabular}

The first until fourteenth data are produced by child A. She produces 14 utterances by omitting the first syllable and producing the last syllable. Furthermore, four data more are produced by child B. They are the fifteenth until eighteenth data. In fifteenth until seventeenth data, she produces the utterances consists of two syllables as target utterance. In the other hand, she applies the omission by deleting the first syllable and producing the last syllable. Then, the last data is osululohproduced by child B. She supposes to say rasulullah as target utterance, but she does not produce correctly due to the fact that she still produces 
limited utterance. Rasulullahto osululohmeans that she is not able to produce the sound of alveolar $/ \mathrm{r} /$ due to the fact that the production system is not ready to articulate [r]. After omitting the sound [r], she also omits 1 consonant in the middle on the word rasulullah. She supposes to pronounces double consonants [l] in the other hand, she only articulates one consonant by applying consonant cluster reductions.

How do the children three-year-old produce the phonology and simplification in acquiring the first language acquisition? Thus, undisputedly the first language acquisition should be seriously discussed. This study found that first language acquisition connected to the phonology. In these views (Dani, 2014; Fatmawati, 2015; Haswadi et al., 2018; Hutauruk, 2015; Narafshan et al., 2014; Ratnaningsih, 2017; Rosdiana, 2016)reveal that there is the steps in acquiring first language acquisition, in which, the children start to acquire the first language since one month. The age of the children determines the way they acquire the first language acquisition. The researchers took the participants in some levels to find the first language acquisition so that the result of those studies was not specific. While, other views (Charlina, 2018; Meniado, 2016; Purba, 2016; Safitri \& Nur Hakim, 2018; Sebayang, 2015; Suwandi, 2012)also supported the statement that the first language acquisition had each level depend on the age of the children. These studies did not observe some levels of the children but the researcher concerned only in one age level of the children in order to find the phonology pattern in first language acquisition. Furthermore, this study agrees with the previous study, in which, certain age of children is observed to find the phonology pattern so that this study conduct the observation in children three-year-old. While this study investigates the phonology pattern in children three-year-old, it also observes the simplification of first language acquisition. It is conducted because the previous studies only observed about the phonology pattern in first language acquisition.

\section{Conclusion}

From the discussion above, it can be concluded that children make the simplification when they want to produce the utterances. First, they do the substitution to replace one segment to another segment. In the substitution of consonant, child A is able to produce the sound of alveolar fricative [s] and velar [k] in the other hand she is able to produce the sound of alveopalatal affricative [ $\mathrm{t}$ ] and [d]]. In child B, she applies gliding on substitution. It means that she is not able to produce sound of alveolar [1] in the other hand she is able to produce the sound of palatal [j]. She also is not able to produce the sound of alveopalatal affricative [d] in the other hand she is able to produce palatal [j]. Second, both child A and B do assimilation when they produce the utterances. Child A applies reduplication by adding the phoneme glottal [?] in the middle of the word. Child B articulates duo to 
be duwoby pronouncing sound [w] clearly. She applies reduplication because she is not able to articulate $/ \mathrm{b} /$ as plosive and change by articulating $/ \mathrm{m} /$ as nasal. Third, both child $\mathrm{A}$ and $\mathrm{B}$ produce the utterances consists of two syllables as target utterance. They apply the omission by deleting the first syllable and producing the last syllable. Child B omits first consonant alveolar [r] due to the fact that the production system is not ready to articulate [r]. she also omits one consonant in the middle from double consonants [1] so that she only articulates one consonant by applying consonant cluster reductions. It means that children absolutely do the simplification, such as substitution, omission and assimilation to help them to produce the utterance when they make the conversation. This study only observes about the phonology is acquired by children three-year-old and the simplification in their interaction. Furthermore, future research is recommended to extend the study with more participants in order to investigate further pattern in first language acquisition.

\section{Acknowledgement}

The researcher would like to thank to Pattani's parents who let their children as participants in this study. They help to take the data by doing the communication with their children. Without their help, this study cannot be conducted.

\section{Refrences}

Ardiana, L. I., \& Sodiq, S. (2008). Psikolinguistik. Jakarta: Universitas Terbuka.

Auerbach, C. F., \& Silverstein, L. B. (2003). Qualitative Data: An Introduction to Coding and Analysis. New York University Press.

Bogdan, R. C., \& Biklen, S. K. (2007). Qualitative Research for Education: An Introduction to Theories and Methods. In Alien and Bacon, Inc, New York. (5th ed.). Allyn and Bacon. https://b-ok.cc/book/2665513/7b28b9

Chaer, A. (2009). Psikolinguistik: Kajian Teoritik. Rineka Cipta.

Charlina, S. E. (2018). First Language Acquisition: A Case Study of Language Disorders in Children (3 Years Old). International Conference on Language, Literature, and Education (ICLLE 2018), 263, 309-314. https://doi.org/10.2991/iclle-18.2018.53

Clark, E. V. (2009). First Language Acquisition (2nd ed.). Cambridge University Press.

Dani, E. P. (2014). The Development of Child Language Acquisition. Jurnal Manajemen Dan Informatika Pelita Nusantara, 15(1), 129-136.

Dardjowidjojo, S. (2003). Psikolinguistik: Pengantar Pemahaman Bahasa Manusia. Yayasan Obor Indonesia.

Fatmawati, S. R. (2015). Pemerolehan Bahasa Pertama Anak Menurut Tinjauan Psikolinguistik. Lentera, 18(1), 63-75. 
The Analysis of Phonology in First Language Acquisition Melayu Pattani in Children Three-Year-Old

Haswadi, M., Syarifudin, \& Rusdiawan. (2018). Children Phonological Acquisition for 3 to 5-Year-Olds. International Journal of Linguistics, Literature and Culture, 4(1), 16-21.

Hutauruk, B. S. (2015). Children First Language Acquisition At Age 1-3 Years Old In Balata. IOSR Journal of Humanities and Social Science (IOSR-JHSS), 20(8), 51-57. https://doi.org/10.9790/0837-20855157

Ingram, D. (1989). First Language Acquisition: Method, Description and Explanation. Cambridge University Press.

Jehwae, P. (2014). Dilema Bahasa Melayu Sebagai Bahasa Pengantar Pembelajaran Di Pondok Pesantren Patani Thailand Selatan. Ta'dib, 19(02), 265-275.

Lust, B. C. (2006). Child Language: Acquisition and Growth. Cambridge University Press.

Meniado, J. C. (2016). First language acquisition : A case study of a three-year old Lebanese child. Journal of Child Language Acquisition and Development - JCLAD, 4(3), 98-112.

Munawir, A. (2019). Online Game and Children's Language Behavior. IDEAS: Journal on English Language Teaching and Learning, Linguistics and Literature, 7(2). doi:https://doi.org/10.24256/ideas.v7i2.1050

Narafshan, M. H., Sadighi, F., Bagheri, M. S., \& Shokrpour, N. (2014). The Role of Input in First Language Acquisition. International Journal of Applied Linguistics \& English Literature, 3(1), 86-91. https://doi.org/10.7575/aiac.ijalel.v.3n.1p.86

Noermanzah. (2017). A 1 . 4 Year Old Child Language Acquisition ( Case Study on a Bilingual Family ). Parole: Journal of Linguistics and Education, 5(2), 145-154. https://doi.org/10.14710/parole.v5i2.11969

Nurhayati, U., \& Nurkholik, N. (2018). The Morphological Processes of Bugis Language (A Morphological Study Of Bugis Language Through Latoa Script). IDEAS: Journal on English Language Teaching and Learning, Linguistics and Literature, 6(1). doi:https://doi.org/10.24256/ideas.v6i1.15

Owens, R. E. (2000). Language Development: An Introduction (8th ed.). Pearson.

Purba, H. S. R. (2016). Phonological Processes in Language Acquisition. English Education, 4(1), 29-44.

Ratnaningsih, E. (2017). An Analysis of the First Language Acquisition: A Two Years Girl. Ahmad Dahlan Journal of English Studies (ADJES), 4(1), 8-14. https://doi.org/10.26555/adjes.v4il.6249

Rosdiana. (2016). Language Acquisition: Classroom Language Acquisition for Preschool Students. Journal of English Language Teaching, 01(01), 63-68.

Safitri, H., \& Nur Hakim, M. (2018). First Language Acquisition of a Three Years Old Child: an Analysis of Phonological Component (a Case Study). IJLECR International Journal of Language Education and Culture Review, 4(2), 150-154. https://doi.org/10.21009/IJLECR.052.18 
ISSN 2338-4778 (Print) ISSN 2548-4192 (Online)

Saldana, J. (2011). Fundamentals of Qualitative Research: Understanding Qualitative Research. Oxford University Press.

Sebayang, S. K. H. (2015). Analisis Pemerolehan Bahasa Pertama (Bahasa Melayu) Pada Anak Usia 3 Tahun. Jurnal Pena Indonesia, 4(1), 80-95.

Suwandi, S. (2012). A Thorough Study on a Child Learning Her First Language: A Case Study on a Three-Year Old Child. ETERNAL (English Teaching Journal), 1(2), 1-15. https://doi.org/10.26877/eternal.v1i2.178

Tarigan, H. G. (2009). Psikolinguistik. Jakarta: Angkasa. 